ENCYCLOPEDDIE Encyclopédie berbère

BERBERE

$23 \mid 2000$

23 | Hiempsal - Icosium

\title{
Iangaukani ou Anagaukani
}

\section{J. Desanges}

\section{OpenEdition}

Journals

Édition électronique

URL : http://journals.openedition.org/encyclopedieberbere/1620

DOI : 10.4000/encyclopedieberbere. 1620

ISSN : 2262-7197

\section{Éditeur}

Peeters Publishers

\section{Édition imprimée}

Date de publication : 1 octobre 2000

Pagination : 3563-3564

ISBN : 2-7449-0207-1

ISSN : 1015-7344

\section{Référence électronique}

J. Desanges, « langaukani ou Anagaukani », Encyclopédie berbère [En ligne], 23 | 2000, document I02, mis en ligne le 01 juin 2011, consulté le 24 septembre 2020. URL : http://journals.openedition.org/ encyclopedieberbere/1620; DOI : https://doi.org/10.4000/encyclopedieberbere.1620

Ce document a été généré automatiquement le 24 septembre 2020.

(C) Tous droits réservés 


\section{Iangaukani ou Anagaukani}

\section{J. Desanges}

1 Les Iangaukani (Anagaukani $X$ ) ne sont mentionnés que par Ptolémée (IV, 1, 5, éd. C. Müller, p. 586), qui les situe apparemment à l'est des Ouoloubiliani*. Il a été question peu auparavant de Kauni*, à l'est, semble-t-il, des Salinsae* (riverains du fleuve Salat, le Bou Regreg ?). Or ces Kauni sont nommés par $X$, manuscrit d'une importance toute particulière dans la tradition du texte de la Géographie, Kaukani. Il faut observer d'autre part, à propos de la forme Iangaukani de l'ethnonyme, que *ng est noté, dans les manuscrits qui la proposent, $n u+$ gamma, une graphie inusuelle en grec. On attendrait un double gamma, le premier gamma notant la nasale devenue gutturale devant une occlusive gutturale. La notation par un $n u$ de cette nasale ne se rencontre que dans certaines inscriptions archaïques (cf. M. Lejeune, Traité de phonétique grecque, Paris, 1947, p. 125). La leçon du manuscrit $X$ : Anagaukani (pour *Anakaukani ?) paraît dès lors préférable.

2 Y a-t-il un rapport entre les Kauni/Kaukani et les Anagaukani? M. Euzennat et R. Rebuffat sont tous deux enclins à les identifier. Le premier les situe entre les Salinsae et les Ouoloubiliani ; le second au sud d'une ligne Sala-Volubilis. Ch. Hamdoune écarte cette identification pour rapprocher le nom des Iangaukani de celui de l'oued Inaouène, qui se jette dans le Sebou au nord-est de Volubilis. Si l'on adopte, comme nous le préconisons, la leçon Anagaukani, le rapprochement demeure possible, mais sans s'imposer.

\section{BIBLIOGRAPHIE}

EUZENNAT M., "Les Zegrenses”, Mélanges d'histoire ancienne offerts à William Seston, Paris, 1974, p. 175-186 (178). 
HAMDOUNE Ch., "Ptolémée et la localisation des tribus de la Tingitane", MEFRA, CV, 1993, p. 241-289 (275).

REBUFFAT R., "Les Baniures. Un nouveau document sur la géographie ancienne de la Maurétanie tingitane", Littérature gréco-romaine et géographie historique. Mélanges offerts à Roger Dion, Paris, 1974 ( = Caesarodunum, IX bis), p. 451-463 (461).

INDEX

Mots-clés : Antiquité, Tribu 